\title{
Enterprise Economic Potential Estimation Model
}

\author{
Olha Komelina* \\ Department of Management and \\ Logistics \\ Poltava National Technical Yuri \\ Kondratyuk \\ Poltava, Ukraine \\ ORCID ID: 0000-0001-9297-4985
}

\author{
Svetlana Shcherbinina \\ Department of Economic Theory and \\ Economic Cybernetics \\ Poltava National Technical Yuri \\ Kondratyuk \\ Poltava, Ukraine \\ ORCID ID: 0000-0002-1034-3619
}

\author{
Maryna Korsunska \\ Department of Management and \\ Logistics \\ Poltava National Technical Yuri \\ Kondratyuk \\ Poltava, Ukraine \\ ORCID 0000-0001-7097-9056
}

\begin{abstract}
In this article for the first time, we have built a model for assessing the economic potential of a transport enterprise, taking into account the production, financial, labor, information and innovative potential of the enterprise. We proposed our grouping of indicators of the effectiveness of the economic potential of the enterprise by its components. We have systematized various indicators, which allows us to clearly see the development of a particular aspect of the enterprise and track the dynamics of changes in each group of indicators separately. We applied an integrated approach to assess the economic potential of an enterprise based on the hierarchy analysis method and the matrix method. We calculated the total economic potential of the enterprise using the Verhulst Equation.

The methodological approach developed by us to assess the economic potential of a transport enterprise - provides a systematic process of control, monitoring the effectiveness of the economic potential with goals and groups of indicators.

This research methodology can be used to assess the economic potential of an enterprise, despite its specific business environment.
\end{abstract}

Keywords-enterprise economic potential, potential components, potential evaluation, hierarchy analysis method, matrix method, Verhulst equation, transport enterprise.

\section{INTRODUCTION}

One of the main issues for modern businesses is to maintain business activity and increase competitiveness in changing terms. Under such terms, the issues of existing enterprise economic potential estimation and improvement system directions substantiation management development become relevant.

The results of assessing enterprise economic potential make it possible to determine the available and hidden opportunities for its formation and use, to determine the quantitative and qualitative resources composition, as well as to justify the prospects for further enterprise development. Components selection of the enterprise economic potential and indicators for estimation construction model is made on the example of the transport enterprise PJSC "Ukrzaliznytsia".

\section{AN OVERVIEW OF RESENT RESEARCHSOURCES AND PUBLICATION}

Formation problems and enterprise economic potential evaluation and its management have been investigated in the works of many scientists, which usually relate to clarifying the concept essence and distinguishing its structural components, as well as approaches to its evaluation, modeling and management of its development. For example, Ting Wang, Bing Chuan Xin, Li Huang Qin (2011) [1] have proposed an approach to assess the enterprise development potential using the analytical hierarchy (AHP) method applied to complex situations decision-making related to planning, resource allocation, prioritization and choice of alternatives. Vytautas Lingaitis, Gintaras Sinkevičius, 2014 proposed an approach to assess the social and economic impact of railway undertakings' potential on the macroeconomic processes of territories [2]. Michele Sabatino (2016) [3] proposed a logical framework for assessing the resilience of industrial enterprises to economic exogenous challenges, based on adaptability principles, flexibility and innovation, and contributing to the creation a new management system. Falko Nordenholz, Christian Winkler, Wolfram Knörr, Falko Nordenholz, Christian Winkler, 2017 examined the issues increasing the attractiveness of railway undertakings and their potential in the travel market in Germany [4]. Theoretical aspects of enterprise economic potential formation were considered by V.V. Prokhorov, O.V. Velichko (2015) [5,6], I.A. Ahaman (2018) [7]. Christopher O.V. applied a systematic approach to assessing the internal capacity and competitiveness of rail transport (2014) [8]. Recent research analysis indicates the need to further improve existing approaches to assessing enterprise economic potential and improving their management effectiveness.

\section{THE MAIN PURPOSE OF THE ARTICLE}

The main study purpose is to develop a universal methodological approach to assess enterprise economic potential, taking into account its components.

\section{THE MAIN RESULTS OF THE RESEARCH}

According to the study results, the feasibility of allocating its production, financial, labor, information and innovation components (potentials), as well as a set of indicators characterizing the various parameters of the efficiency and determining the overall economic potential assessment model, are substantiated. Given the need for a general assessment economic potential and the evaluation of its components, it was decided to use expert methods, in particular the method of Thomas Saati analytical hierarchies [9]. The advantage of this method is the ability to simultaneously work with qualitative and quantitative information. Components selection and indicators for the construction estimation model was made on transport enterprise of PJSC "Ukrzaliznytsia” example (Table 1). 
For each component of the enterprise econonomic potential, several indicators were selected that affect its overall score. At the same time, all indicators that characterize the information and innovation components of the EPA are dimensionless units. They are formed as the ratio of the size of a portion of a sample that has a specific property to the total size of the sample.

Note that this list of groups of indicators can be modified or revised depending on the specific economic activity at a particular enterprise, the goals of the researchers and the purpose of the assessment.

In order to assess the enterprise economic potential and to define certain variables, it is proposed to use the method of expert evaluation, which requires the involvement of a special group of experts (3-10 people). The study included people with different types of thinking - figurative and verbal-logical, which contributed to the successful completion of the task. The experts involved expressed their views on the indicators of every potential components.

According to the developed hierarchies criteria, a consistent evaluation of enterprise economic potential was performed. The first step is to determine the weight of the criteria for each structural part of enterprise economic potential for production, financial, labor, information, innovation potentials. For each direction, a table of paired comparison indicators for every type of potential is created according to the sample below (Table 2).

TABLE I. POTENTIAL PARAMETERS COMPARISON MATRIX

\begin{tabular}{|c|c|c|c|c|c|c|c|}
\hline & $\mathbf{C}_{1}$ & $\mathbf{C}_{2}$ & $\ldots$ & $\mathbf{C}_{\mathbf{n}}$ & $\begin{array}{c}\text { Main } \\
\text { eigenvector, } \mathbf{a}_{\mathbf{i}}\end{array}$ & $\begin{array}{c}\text { Priorities } \\
\text { vector, } \mathbf{x}_{\mathbf{i}}\end{array}$ & $\begin{array}{c}\text { Own } \\
\text { values, } \boldsymbol{\lambda}_{\mathbf{i}}\end{array}$ \\
\hline $\mathbf{C}_{\mathbf{1}}$ & $\mathrm{V}_{1} / \mathrm{V}_{1}$ & $\mathrm{~V}_{1} / \mathrm{V}_{2}$ & $\ldots$ & $\mathrm{V}_{1} / \mathrm{V}_{1}$ & $\mathrm{a}_{1}$ & $\mathrm{X}_{1}$ & $\lambda_{1}$ \\
\hline $\mathbf{C}_{2}$ & $\mathrm{~V}_{2} / \mathrm{V}_{1}$ & $\mathrm{~V}_{2} / \mathrm{V}_{2}$ & $\ldots$ & $\mathrm{V}_{2} / \mathrm{V}_{1}$ & $\mathrm{a}_{2}$ & $\mathrm{X}_{2}$ & $\lambda_{2}$ \\
\hline$\ldots$ & $\ldots$ & $\ldots$ & $\ldots$ & $\ldots$ & & & \\
\hline $\mathbf{C}_{\mathbf{n}}$ & $\mathrm{V}_{\mathrm{n}} / \mathrm{V}_{1}$ & $\mathrm{~V}_{\mathrm{n}} / \mathrm{V}_{1}$ & $\ldots$ & $\mathrm{V}_{\mathrm{n}} / \mathrm{V}_{\mathrm{n}}$ & $\mathrm{a}_{\mathrm{n}}$ & $\mathrm{x}_{\mathrm{n}}$ & $\lambda_{\mathrm{n}}$ \\
\hline
\end{tabular}

Within the matrix, all parameters are compared in pairs based on the intensity of influence on the total indicator of economic potential and the weight of each parameter is determined. If we denote the parameters by $C_{1}, C 2, \ldots C_{n}$, then the row determines the degree of dominance (dominance) of the factor from the left column over each of the factors from the top row, sequentially. The weight of the factor is denoted respectively by $V_{l}, V_{2}, \ldots V_{n}$. If the weight of factors $\left(V_{x}\right)$ is unknown in advance, it is determined by a fundamental scale of absolute values for evaluating the strength of expert judgment by the method of analytical hierarchies by T. Saati.

TABLE II. PJSC "UKRZALIZNITSIA ECONOMIC POTENTIAL INDICATORS DEFINITION"

\begin{tabular}{|c|c|}
\hline Indicator & Unit \\
\hline \multicolumn{2}{|r|}{ Production potential } \\
\hline Wear ratio & $\begin{array}{l}\text { Characterizes the degree of deterioration fixed assets. It is calculated as the ratio of depreciation amuont fixed assets to their } \\
\text { original cost. }\end{array}$ \\
\hline $\begin{array}{l}\text { The growth fixed assets } \\
\text { RatioR }_{\mathrm{g}} \text {. }\end{array}$ & $\begin{array}{l}\text { Describes the degree of increase in fixed assets in the reporting period against the past. It is calculated as the ratio of the } \\
\text { difference between the input and output of fixed assets to their book value. }\end{array}$ \\
\hline Financial return, $\mathrm{R}_{\mathrm{f}}$ & $\begin{array}{l}\text { Characterizes the efficiency ofbasic production stocks usage, reflects the amount of products produced per UAH } 1 \text { of the } \\
\text { basic production stocks. It is calculated as the ratio of the value manufactured products to the carrying amount fixed assets. }\end{array}$ \\
\hline Return on fixed assets $\mathrm{R}_{\mathrm{r}}$ & $\begin{array}{l}\text { Describes the share of the enterprise's profit for the year from the value of fixed assets. It is calculated as the ratio of profit } \\
\text { from the main production and enterprise non-productive activity to the average annual value of fixed assets. }\end{array}$ \\
\hline \multicolumn{2}{|r|}{ Financial potential } \\
\hline Autonomy coefficient, $\mathrm{R}_{\text {aut }}$ & $\begin{array}{l}\text { Characterizes the dependence of the enterprise on external sources of financing. It is calculated as the ratio of the equity of } \\
\text { the enterprise to liabilities amount }\end{array}$ \\
\hline Current liquidity ratio. $\mathrm{R}_{1}$ & $\begin{array}{l}\text { It describes the proportion of current liabilities that may be covered not only by existing assets but also by future assets. It is } \\
\text { calculated as the ratio of current assets and future expenses to long-term liabilities, current liabilities and future income. }\end{array}$ \\
\hline Asset Profitability Ratio $\mathrm{R}_{\mathrm{ra}}$ & $\begin{array}{l}\text { Describes the efficiency of use of all assets of the enterprise. It is calculated as the ratio of net income to assets (total } \\
\text { capital). }\end{array}$ \\
\hline Return on Equity Ratio, $\mathrm{R}_{\mathrm{rc}}$ & es the percentage of return on equity. It is calcu \\
\hline $\begin{array}{c}\text { "aging" labor resources ratio } \\
\mathrm{R}_{\mathrm{la}}\end{array}$ & $\begin{array}{l}\text { Describes the percentage of employees over the age of } 60 \text { in the total number of employees at the enterprise. It is calculated } \\
\text { as the ratio of the number of employees at retirement age to the number of employees. }\end{array}$ \\
\hline $\begin{array}{c}\text { Persistence personnel ratio, } \\
\mathrm{R}_{\mathrm{pp}} \\
\end{array}$ & $\begin{array}{l}\text { Describes the proportion of employees who have been employed for more than } 1 \text { year. It is calculated as the ratio of the } \\
\text { number of employees who worked throughout the year to the number of employees. }\end{array}$ \\
\hline $\begin{array}{l}\text { Professional Development } \\
\text { Ratio } \mathrm{R}_{\mathrm{pd}}\end{array}$ & $\begin{array}{l}\text { Describes the proportion of staff who during the analyzed period made improvements in professional knowledge, skills, } \\
\text { profession. It is calculated as the ratio of the number of employees who during the analyzed period increased their } \\
\text { qualification level to the total number of employees. }\end{array}$ \\
\hline $\begin{array}{l}\text { Personnel profitability } \\
\text { ratio, } R_{p}\end{array}$ & $\begin{array}{l}\text { Describes how effectively staffing costs are used (salaries, incentives, holidays, social benefits, job retention). It is calculated } \\
\text { as the ratio of operating profit to the average annual number of industrial production personnel. }\end{array}$ \\
\hline \multicolumn{2}{|r|}{ Information potential } \\
\hline Completeness Index, , $\mathrm{I}_{\mathrm{p}}$ & $\begin{array}{l}\text { The ratio of information amoiunt available to the decision maker to the amount of information needed to make that decision } \\
\text { is } I_{p} 0,1[0,1] \text {. }\end{array}$ \\
\hline $\begin{array}{l}\text { Index of accuracy } \\
\text { information, } I_{t}\end{array}$ & The ratio of the amount of relevant (reliable) information to the total amount of information available, $I_{t}[0,1]$ \\
\hline $\begin{array}{l}\text { Index of information } \\
\text { conflicts } I_{c}\end{array}$ & $\begin{array}{l}\text { The ratio of the number of independent testimony in favor of making a decision to the total number of independent } \\
\text { testimony in the total amount of relevant information, } \mathrm{I}_{c} 0,1[0,1] \text {. }\end{array}$ \\
\hline \multicolumn{2}{|r|}{ Innovative potential } \\
\hline $\begin{array}{l}\text { The level of perception } \\
\text { innovation by the staff, } \mathrm{J}_{\mathrm{s}}\end{array}$ & terprise to the introduced innovative developments, Js 0,1 \\
\hline
\end{tabular}


The calculation of the own vector matrix is as follows:

1) The geometric mean for each row of the pairwise comparison matrix (a new column) defining the components of the eigenvector of matrix $A$. The components of the eigenvector of the matrix are given by formulas (1-3):

$$
\begin{gathered}
a_{1}=\sqrt[n]{\left[\frac{V_{1}}{V_{1}} * \frac{V_{2}}{V_{2}} \ldots \frac{V_{1}}{V_{n}}\right]} \quad \text { (1) } \quad a_{3}=\sqrt[n]{\left[\frac{V_{3}}{V_{1}} * \frac{V_{3}}{V_{2}} \ldots \frac{V_{3}}{V_{n}}\right]} \\
a_{i}=\sqrt[n]{\prod_{i=1}^{n} V_{i}}, \text { де } i=1,2, \ldots n
\end{gathered}
$$

2) The sum of the elements in this column (the sum of the elements of the eigenvector of matrix $A$ ) is obtained for further normalization (to obtain the priority vector).

$S_{a}$ - the sum of the components values matrix eigenvector (4):

$$
S_{a}=a_{1}+a_{2}+\ldots+a_{n}
$$

3) Each element of the new column is divided by the amount received (the operation of normalization of values), and the components of the priority vector are obtained.

Priority Vector Components (5):

$$
X=\left(x_{1}, x_{2}, x_{3} \ldots x_{n}\right),
$$

where $x_{1}, x_{2}, x_{3} \ldots x_{n}$ - the value of the components priority vector, defined by the formulas $(6-9)$ :

$$
x_{1}=\frac{a_{1}}{S_{a}}, \text { (6) } \quad x_{2}=\frac{a_{2}}{S_{a}}, \text { (7) } \quad x_{3}=\frac{a_{3}}{S_{a}},
$$

where $\mathrm{S}_{\mathrm{a}}$-the sum of the values eigenvectors matrix $A$

$$
X_{i}=\frac{a_{i}}{\sum_{i=1}^{n} a_{i}}, \text { de } i=1,2, \ldots n .
$$

4) The maximum eigenvalue (value) of the matrix according to the formula (10) is calculated:

$$
\lambda_{i}=\frac{\left(\sum_{i=1}^{n} v_{i} a_{i}\right.}{a_{i}}, \text { de } i=1,2, \ldots n .
$$

To calculate $\lambda$ max, the sum for each column of the matrix is determined and multiplied by the corresponding component of the priority vector (11). Or use the generalized formula (12):

$$
\lambda_{\max }=\sum_{1} * x_{1}+\sum_{2} * x_{2}+\sum_{\beta} * x_{3}+\cdots \sum_{n} * x_{n}
$$

where $\Sigma_{1}, \Sigma_{2}, \Sigma_{3} \ldots \Sigma_{n}$-the sum of the elements corresponding columns of matrix A.

$$
\lambda_{\max }=\frac{\sum_{i=1}^{n} \lambda_{i}}{n},
$$

5) The consistency of expert estimates was determined by determining the consistency ratio. As a measure of consistency, an indicator is adopted - the index of consistency $\mathrm{I}_{\mathrm{y}}$, which is compared to the average random reference value of the $C B_{y}$ in the form of a ratio. Thus, the consistency index and the consistency ratio $B_{y}$ are calculated by the formulas (13-14):

$$
B_{y}=\left(I_{y} / C B_{y}\right), \leq 10 \%
$$

where $B_{y}$ - consistency ratio; $I_{y}-$ consistency index; $C B_{y}$ - a value corresponding to the value of the average random agreement for a matrix of a certain order.

$$
I_{y}=\frac{\lambda_{\max }-n}{n-1},
$$

where $n$ - items quantity being compared, $\lambda \max -$ estimated value.

The results of the experts' surveys and the evaluation of their judgments have been reduced to average and a collective result has been formed from the evaluation of the judgments of the members of the expert group.

To determine the weight coefficients for the calculation of production potential, the method of expert estimations was used. According to the results of the survey every 3 experts, matrices of paired comparisons were compiled. The matrices are $4 \times 4$ in size, in terms of production, financial, labor and $3 \times 3$ indicators for information and innovation potentials. For example, the number 2 at the intersection of the first row and the second column of the matrix $R_{l}$ means that from the point of view of the first expert, the wear factor has a slight degree of advantage over the coefficient of growth in determining the production potential.

The implementation of this model was carried out in the Microsoft Excel spreadsheet environment, the results of the calculation of the priority vectors and weights are presented by the example of production potential, Figure $1-3$.

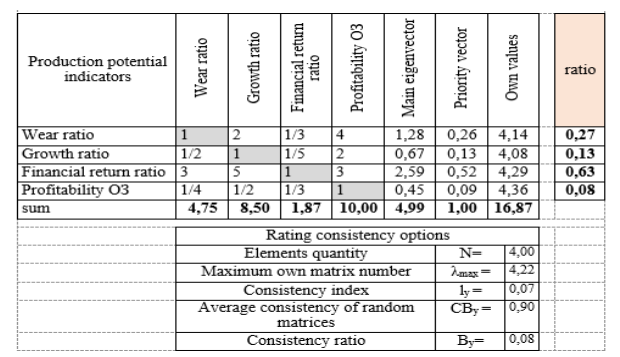

Fig. 1. Assessment of production potential indicators of PJSC "Ukrzaliznytsia" by 1 expert

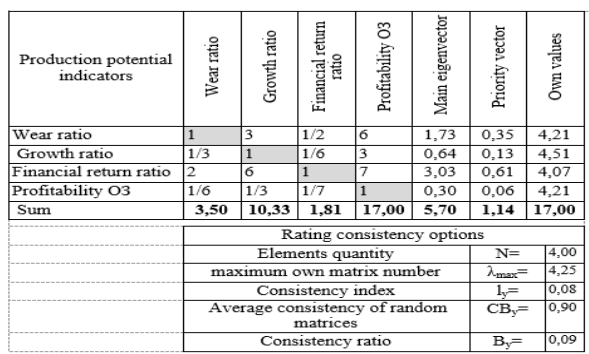

Fig. 2. Expert's assessment of production potential of PJSC "Ukrzaliznytsia" 


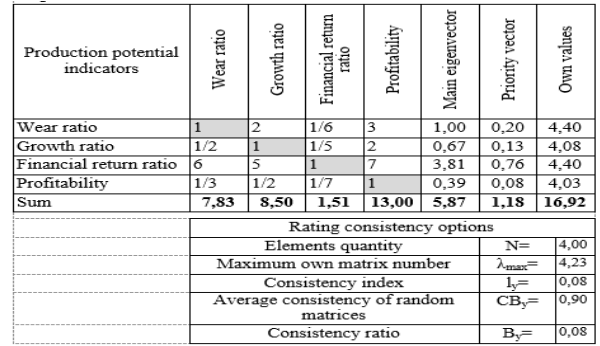

Fig. 3. Expert's assessment of the production potential of PJSC "Ukrzaliznytsya"

Tables 3 - 7 summarize the maximal eigenvalues of the $\lambda$ max matrices of the pairwise comparisons for each potentials in the enterprise economic potential and the eigenvectors corresponding to these eigenvalues $\vec{v}$.

TABLE III. MAXIMUM Eigenvalues $\lambda_{\max }$ MATRIX PAIR COMPARISONS PRODUCTION POTENTIAL

\begin{tabular}{|c|c|c|}
\hline Matrix number & $\boldsymbol{\lambda}_{\max }$ & $\vec{v}$ \\
\hline 1 & 4,22 & $(0,26 ; 0,13 ; 0,52 ; 0,09)$ \\
\hline 2 & 4,25 & $(0,35 ; 0,13 ; 0,61 ; 0,06)$ \\
\hline 3 & 4,23 & $(0,20 ; 0,13 ; 0,76 ; 0,08)$ \\
\hline
\end{tabular}

TABLE IV. MAXIMUM EIGENVALUES $\Lambda_{\text {MAX }}$ MATRIX PAIR COMPARISONS FINANCIAL POTENTIAL

\begin{tabular}{|c|c|c|}
\hline Matrix number & $\boldsymbol{\lambda}_{\max }$ & $\vec{v}$ \\
\hline 1 & 4,17 & $(0,57 ; 0,08 ; 0,30 ; 0,05)$ \\
\hline 2 & 4,14 & $(0,57 ; 0,08 ; 0,26 ; 0,05)$ \\
\hline 3 & 4,20 & $(0,50 ; 0,11 ; 0,28 ; 0,04)$ \\
\hline
\end{tabular}

TABLE V. MAXIMUM EIGENVALUES $\Lambda_{\text {MAX }}$ MATRIX PAIR COMPARISONS LABOR POTENTIAL

\begin{tabular}{|c|c|c|}
\hline Matrix number & $\boldsymbol{\lambda}_{\max }$ & $\vec{v}$ \\
\hline 1 & 4,19 & $(0,52 ; 0,33 ; 0,07 ; 0,08)$ \\
\hline 2 & 4,15 & $(0,49 ; 0,29 ; 0,11 ; 0,06)$ \\
\hline 3 & 4,09 & $(0,51 ; 0,33 ; 0,06 ; 0,10)$ \\
\hline
\end{tabular}

TABLE VI. MAXIMUM EIGENVALUES $\Lambda_{\text {MAX }}$ MATRIX PAIR COMPARISONS INFORMATION POTENTIAL

\begin{tabular}{|c|c|c|}
\hline Matrix number & $\boldsymbol{\lambda}_{\max }$ & $\vec{v}$ \\
\hline 1 & 3,01 & $(0,32 ; 0,59 ; 0,09)$ \\
\hline 2 & 3,07 & $(0,28 ; 0,67 ; 0,09)$ \\
\hline 3 & 3,06 & $(0,37 ; 0,62 ; 0,07)$ \\
\hline
\end{tabular}

TABLE VII. MAXIMUM EIGENVALUES $\Lambda_{\text {MAX }}$ MATRIX PAIR COMPARISONS INNOVATION POTENTIAL

\begin{tabular}{|c|c|c|}
\hline Matrix number & $\boldsymbol{\lambda}_{\max }$ & $\vec{v}$ \\
\hline 1 & 3,09 & $(0,54 ; 0,10 ; 0,36)$ \\
\hline 2 & 3,02 & $(0,61 ; 0,09 ; 0,34)$ \\
\hline 3 & 3,09 & $(0,61 ; 0,08 ; 0,39)$ \\
\hline
\end{tabular}

The priority vector (weighting coefficients) is a normalized eigenvector of the pairwise comparison matrix that corresponds to its maximum eigenvalue. Table $8-12$ display the obtained priority vectors corresponding to the conclusions of 3 experts and the consistency indices of the matched pair matrices, which are calculated by the formula (14). The consistency index shows how close the pairwise comparison matrix is to a fully matched matrix.

It is known that the average value of the random consistency index for $n=4$ is 0.9 and for $n=3$ it is 0.58 . The consistency indices of the matrices of each potentials are substantially less than this value. Therefore, the expert judgment can be regarded as inconsistent.
TABLE VIII. CONSISTENCY MATRIX PAIR COMPARISONS PRODUCTION POTENTIAL

\begin{tabular}{|c|c|c|c|}
\hline $\begin{array}{c}\text { Matrix } \\
\text { number }\end{array}$ & $\vec{v}$ norm & $\begin{array}{c}\text { Consistency } \\
\text { index }\end{array}$ & $\begin{array}{c}\text { Consistency } \\
\text { ratio }\end{array}$ \\
\hline 1 & $(0,26 ; 0,13 ; 0,52 ; 0,09)$ & 0,07 & 0,08 \\
\hline 2 & $(0,35 ; 0,13 ; 0,61 ; 0,06)$ & 0,08 & 0,09 \\
\hline 3 & $(0,20 ; 0,13 ; 0,76 ; 0,08)$ & 0,08 & 0,08 \\
\hline
\end{tabular}

TABLE IX. CONSISTENCY INDEX MATRIX PAIR COMPARISONS FINANCIAL POTENTIAL

\begin{tabular}{|c|c|c|c|}
\hline $\begin{array}{c}\text { Matrix } \\
\text { number }\end{array}$ & $\vec{v}$ norm & $\begin{array}{c}\text { Consistency } \\
\text { index }\end{array}$ & $\begin{array}{c}\text { Consistency } \\
\text { ratio }\end{array}$ \\
\hline 1 & $(0,57 ; 0,08 ; 0,30 ; 0,05)$ & 0,06 & 0,06 \\
\hline 2 & $(0,57 ; 0,08 ; 0,26 ; 0,05)$ & 0,05 & 0,05 \\
\hline 3 & $(0,50 ; 0,11 ; 0,28 ; 0,04)$ & 0,07 & 0,08 \\
\hline
\end{tabular}

TABLE $X$. CONSISTENCY INDEX MATRIX PAIR COMPARISONS LABOR POTENTIAL

\begin{tabular}{|c|c|c|c|}
\hline $\begin{array}{c}\text { Matrix } \\
\text { number }\end{array}$ & $\vec{v}$ norm & $\begin{array}{c}\text { Consistency } \\
\text { index }\end{array}$ & $\begin{array}{c}\text { Consistency } \\
\text { ratio }\end{array}$ \\
\hline 1 & $(0,52 ; 0,33 ; 0,07 ; 0,08)$ & 0,06 & 0,07 \\
\hline 2 & $(0,49 ; 0,29 ; 0,11 ; 0,06)$ & 0,05 & 0,06 \\
\hline 3 & $(0,51 ; 0,33 ; 0,06 ; 0,10)$ & 0,03 & 0,03 \\
\hline
\end{tabular}

TABLE XI. CONSISTENCY INDEX MATRIX PAIR COMPARISONS INFORMATION POTENTIAL

\begin{tabular}{|c|c|c|c|}
\hline $\begin{array}{c}\text { Matrix } \\
\text { number }\end{array}$ & $\vec{v}$ norm & $\begin{array}{c}\text { Consistency } \\
\text { index }\end{array}$ & $\begin{array}{c}\text { Consistency } \\
\text { ratio }\end{array}$ \\
\hline 1 & $(0,32 ; 0,59 ; 0,09)$ & 0,005 & 0,01 \\
\hline 2 & $(0,28 ; 0,67 ; 0,09)$ & 0,04 & 0,06 \\
\hline 3 & $(0,37 ; 0,62 ; 0,07)$ & 0,03 & 0,05 \\
\hline
\end{tabular}

TABLE XII. CONSISTENCY INDEX MATRIX PAIR COMPARISONS INNOVATIVE POTENTIAL

\begin{tabular}{|c|c|c|c|}
\hline $\begin{array}{c}\text { Matrix } \\
\text { Number }\end{array}$ & $\vec{v}$ norm & $\begin{array}{c}\text { Consistency } \\
\text { index }\end{array}$ & $\begin{array}{c}\text { Consistency } \\
\text { ratio }\end{array}$ \\
\hline 1 & $(0,54 ; 0,10 ; 0,36)$ & 0,05 & 0,08 \\
\hline 2 & $(0,61 ; 0,09 ; 0,34)$ & 0,01 & 0,02 \\
\hline 3 & $(0,61 ; 0,08 ; 0,39)$ & 0,04 & 0,07 \\
\hline
\end{tabular}

To define the weight ratio $\mathrm{R}_{x}$, the usual averaging the normalized eigenvectors is used, $\mathrm{n}$ is matrix dimension

$$
e_{x}=\frac{1}{n} \sum_{i=1}^{n} v_{n o r m, x, i}
$$

Weight coefficients for each components of economic potential are calculated, Table. 13

TABLE XIII. POTENTIAL WEIGHT RATIO

\begin{tabular}{|c|c|c|c|c|c|}
\hline & PP & FP & LP & IP & InP \\
\hline e1 & 0,27 & 0,55 & 0,51 & 0,33 & 0,59 \\
\hline e2 & 0,13 & 0,09 & 0,31 & 0,63 & 0,09 \\
\hline e3 & 0,63 & 0,28 & 0,08 & 0,08 & 0,36 \\
\hline e4 & 0,08 & 0,05 & 0,08 & - & - \\
\hline
\end{tabular}

Formulas for calculating each potential are given in Table. 14.

It should be noted that determining only one of the components the potential is not a solution to the task of assessing the economic potential of the enterprise. Therefore, it is proposed to use the matrix method of estimating economic potential by determining the indices of the component potentials (Figure 4).

The values of the axes matrix are defined by the convolution method as weighted average integral values, where the values of the indicators and their weight 
coefficients are determined by experts using the Saati hierarchy method.

\section{TABLE XIV. FORMULAS FOR CALCULATION OF POTENTIALS}

\begin{tabular}{|c|c|}
\hline Potential type & Formula \\
\hline Production potential & $0,27 \mathrm{Rw}+0,13 \mathrm{R}_{\mathrm{r}}+0,63 \mathrm{~F}_{\mathrm{f}}+0,08 \mathrm{Kg}$ \\
\hline Financial potential & $0,55 \mathrm{R}_{\mathrm{aut}}+0,09 \mathrm{R}_{\mathrm{lp}}+0,28 \mathrm{R}_{\mathrm{pa}}+0,05 \mathrm{R}$ \\
\hline Labor potential & $0,51 \mathrm{R}_{\mathrm{la}}+0,31 \mathrm{R}_{\mathrm{pp}}+0,08 \mathrm{R}_{\mathrm{pd}}+0,08 \mathrm{R}_{\mathrm{p}}$ \\
\hline Information potential & $0,33 \mathrm{I}_{\mathrm{p}}+0,63 \mathrm{I}_{\mathrm{t}}+0,08 \mathrm{I}_{\mathrm{c}}$ \\
\hline Innovative potential & $0,59 \mathrm{~J}_{\mathrm{a}}+0,09 \mathrm{~J}_{\mathrm{z}}+0,36 \mathrm{~J}_{\mathrm{o}}$ \\
\hline
\end{tabular}

\begin{tabular}{c|c|c|c|}
\cline { 2 - 4 } high & Sufficient level EP & High level EP & High level EP \\
\cline { 2 - 4 } $\begin{array}{c}\text { average } \\
\text { low }\end{array}$ & Low level EP & Sufficient level EP & High level EP \\
\cline { 2 - 4 } & Low level EP & Low level EP & Low level EP \\
\cline { 2 - 4 } & &
\end{tabular}

Fig. 4. Matrix of pair comparison enterprise parameters economic potential

Thus, within the matrix are considered three variants of the result of assessment of the economic potential of the enterprise: 1) "low EP" the economic potential of the enterprise is not effective, it is necessary to carry out additional analysis to identify and eliminate all deficiencies, 2) "sufficient EP" economic potential is conditionally effective, ie it is necessary to investigate the cause of low values of components of economic potential to eliminate them in the further activity of the enterprise; 3) "high level of EP" - economic potential is effectively used in the enterprise, it is necessary to take into account the positive experience in planning and implementation of measures to increase economic potential. The scale of economic potential assessment has three boundary divisions: 3, 6, 9. These numbers are absolute and determined by expert survey.

Production, financial and labor potentials have been calculated for PJSC "Ukrzaliznytsya". The calculations were made based on quarterly financial statements for two years. The values obtained were normalized using a stabilizer (16) and a destabilizer (17):

$$
x^{\prime}=\frac{x-x_{\min }}{x_{\max }-x_{\min }} \quad(16) \quad x^{\prime}=\frac{x_{\max }-x}{x_{\max }-x_{\min }}
$$

The results are presented in Figure 5. Normalized data are presented in Figure 6.

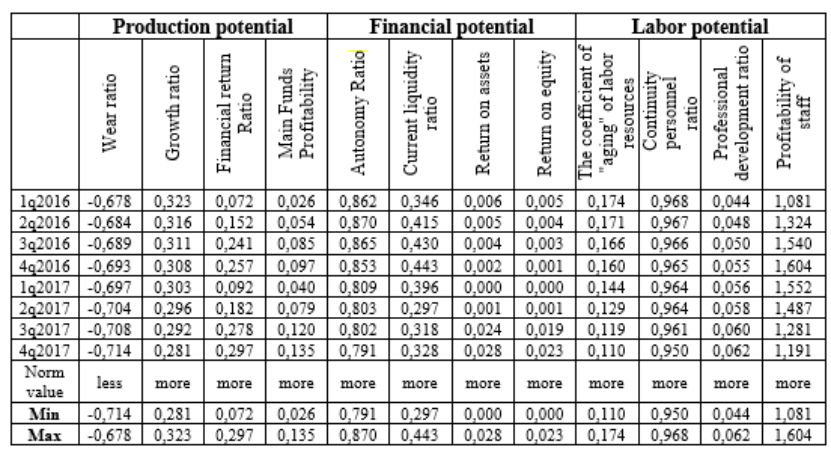

Fig. 5. Ratio of PP, FP and LP for PJSC "Ukrzaliznytsia"

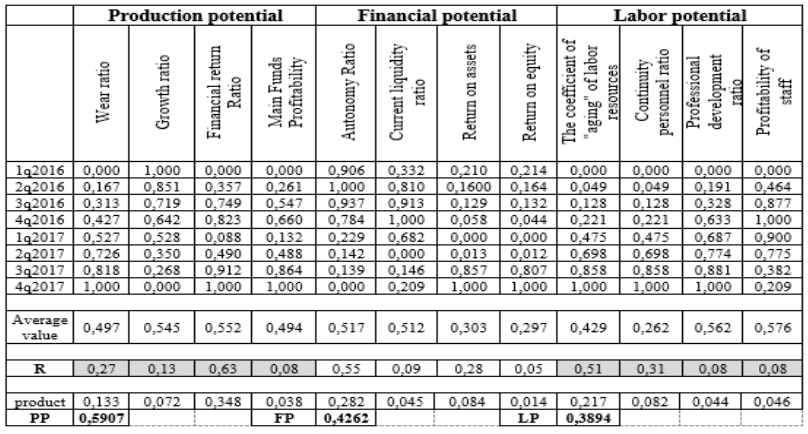

Fig. 6. Normalized ratio given by PJSC "Ukrzaliznytsia"

The equations (Table 14) determine the level of potential utilization: production potential - 59,07\%; financial potential - 42,62\%; labor potential - 38,94\%.

To apply the matrix method inpotential estimation, it will be determined the absolute estimation of their indicators (Table 15). As a result of the research indicators of efficiency potentials and their weight coefficients for PJSC "Ukrzaliznytsia" are obtained. So:

$\mathrm{S} 1=($ Production; If; Ilab $)=(6.20 ; 6.07 ; 4.96)$,

$\mathrm{S} 2=($ Iinf $;$ Iin $)=(2.88 ; 2.63)$.

A graphical representation components of economic potential is presented in Figure 7-8.

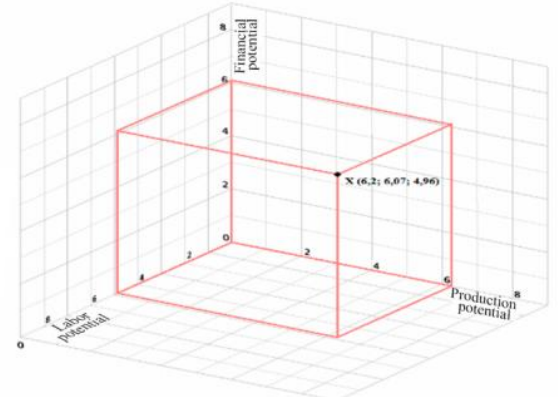

Fig. 7. Graphical representation of PP, FP and LP PJSC Ukrzaliznytsia

Therefore, according to the first group indicators, the economic potential of the studied enterprise PJSC "Ukrzaliznytsia" is sufficient, while for the second group indicators it is low.

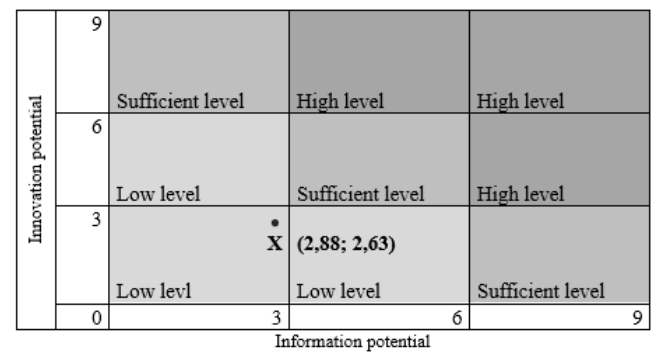

Fig. 8. Graphical representation of IP and InP of PJSC "Ukrzaliznytsia"

There is a need for more detailed study unsatisfactory level of information and innovation potentials in order to increase the overall level of economic potential of Ukrzaliznytsia.

In spite of the advantages the proposed matrix, there are also some limitations, which are related, first of all, to the qualifications of experts and the subjectivity of their evaluations. 
TABLE XV. ABSOLUTE ASSESSMENT POTENTIALS CALCULATION PJSC "UKRZALIZNITSA"

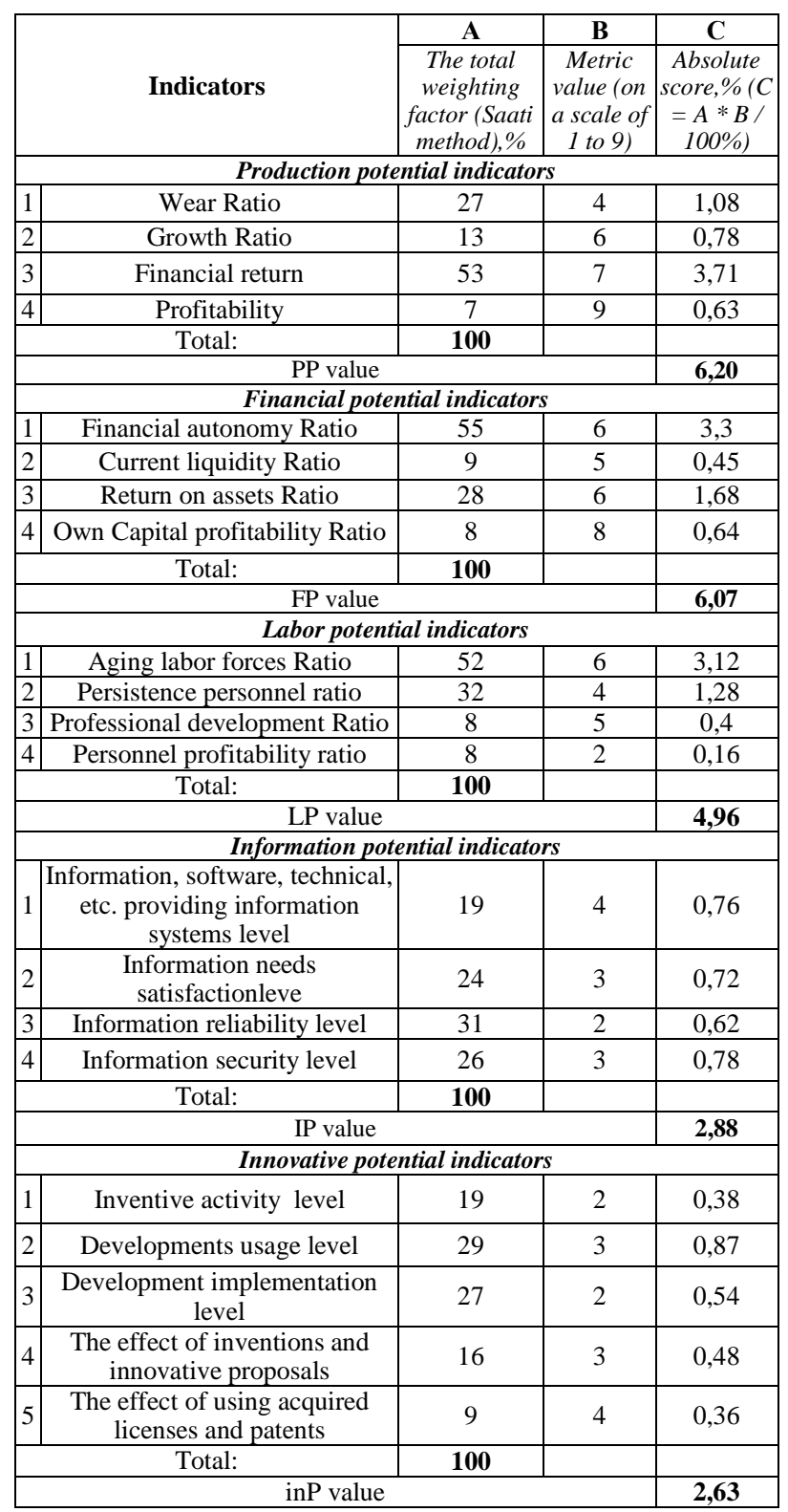

For many economic processes description, they usually use an exponential equation, but this equation has no threshold. Therefore, a logistic equation, also known as the Verhulst equation [10], was used to represent the overall results of the study the economic potential of Ukrzaliznytsia.

$$
P(t)=\frac{K P_{0} e^{r t}}{K+P_{0}\left(e^{r t}-1\right)}
$$

wher $K$-maximum threshold value; $P_{0}$-the initial threshold value, 0,$1 ; e$-constant value, 2,$73 ; r$-weighting potential value; $t$-is an absolute potential estimate.

The overall estimate of the economic potential PJSC "Ukrzaliznytsia", which is 5.2 and is within [3;6] is obtained. It indicates a sufficient potential level PJSC "Ukrzaliznytsya" (Figure 9).

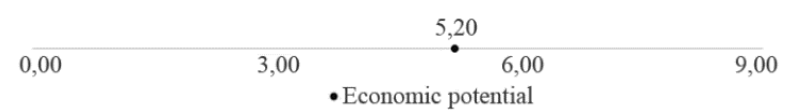

Fig. 9. Economic potential graphical representation

\section{CONCLUSIONS}

The study results provide an opportunity to comprehensively assess the enterprise state, its resources, the efficiency of use existing economic potential, taking into account the selected components, as well as to find opportunities for its growth, to justify the managerial decisions that are made.

The proposed enterprise economic potential modelestimation enables to determine the degree of influence the most important factors, when analytical hierarchical process method was used. It is substantiated that enterprise economic potential indicators estimation system should take the form of a hierarchical structure, which will enable to detail or integrate the indicators characterizing potentials states (resources) different types, to define stock reserves and their usage directions, to substantiate enterprise further development economic policy.

Thus, the proposed economic potential assessment model, which is based on the interconnectedness and consistency of 5 assessment indicators levels, enables to compare, analyze, evaluate in details the degree of an enterprise economic activity utilization resources at different levels.

\section{REFERENCES}

[1] Ting Wang, Bing chuan Xin, and Li juan Qin, "APH-based capacity evaluation of enterprise development", Procedia Engineering., vol. 15, pp. 4693-4696, 2011. https://doi.org/10.1016/j.proeng.2011.08.878

[2] Vytautas Lingaitis, and Gintaras Sinkevičius, "Passenger transport by railway: evaluation of economic and social phenomenon", Procedia - Social and Behavioral Sciences., vol. 110, pp. 549-559, 2014. https://doi.org/10.1016/j.sbspro.2013.12.899

[3] Michele Sabatino, "Economic crisis and resilience: resilient capacity and competitiveness of the enterprises", Journal of Business Research., $\quad$ vol. 69, pp. 1924-1927, 2016. https://doi.org/10.1016/j.jbusres.2015.10.081

[4] Falko Nordenholz, Christian Winkler, and Wolfram Knörr,. "Analysing the modal shift to rail potential within the long-distance passenger travel market in Germany", Transportation Research Procedia., vol. 26, pp. 81-91, 2017. https://doi.org/10.1016/j.trpro.2017.07.010

[5] V. Prokhorov., And D. Tarasyuk, "Forming the Economic Potential of an Enterprise: Theoretical Aspect," Economy and Region, No. 4, pp. 35-39, 2015. [in Ukrainian].

[6] O. Velichko, "The Essence of the Economic Potential of an Enterprise", Actual Problems of Economics, No. 9, pp. 15-20, 2015. [in Ukrainian]

[7] I. Azhaman and O. Zhidkov, "The essence and structure of the economic potential of the enterprise", Economy and State, No. 4, pp 22-25, 2018. [in Ukrainian].

[8] O. Christopher, "A Systematic Approach to Assessing the Internal Capacity and Competitiveness of Rail Transport as a Basis for Creating a Balanced Scorecard", Transport Economics, No. 8, pp. 31-41, 2014. [in Ukrainian].

[9] O. Tkachova, "The Saati Method in Managerial Decision Making", States and Regions, No. 4, p. 92-96, 2015. [in Ukrainian].

M. Muzychenko, "The Use of the Verhulst Logistic Function as a Desirability Function for Normalizing the Indicators of Security of Natural Gas Supply", Economics and Society, No. 9, p. 83-88, 2017. [in Ukrainian] 